\title{
FORMATION OF LINGUISTIC IDENTITY OF SOCIETY
}

\section{Yursa Lyudmyla ${ }^{1}$}

DOI: https://doi.org/10.30525/978-9934-571-89-3_7

The environment in which there is a person, forms its outlook, its own ethnic and cultural affiliation. Due to these or other circumstances, constructive changes are in the consciousness of society. Detachment or linguistic isolation from the general language development in other territories whose inhabitants belong to the same ethnic group may lead to language destabilization and threats to the territorial integrity of the state.

We want to consider such a problem on the example of Transcarpathian lands of Ukraine. Despite its Central European location, the Transcarpathian lands to the nineteenth century, were gray zone both in the Ukrainian and in the Central European space.

At the end of the nineteenth century, the revival wave of the national identity of ukrainians in Galicia and Bukovina began to reach the lands of historical Transcarpathia. Local Hungarian leadership and Muscovite propagandists tried to find methods that would oppose all sorts of Ukrainian concepts. They stopped their attention to the idea of Transcarpathians separation from all-Ukrainian context. According to L. Belya, "the separateness of the autochthonous population of the historical Transcarpathian region due to its anti-Ukrainian nature was surprisingly versatile, before the end of the Second World War was perfectly suited to the imperial and revanchist forces of Russia, Hungary, Czechoslovakia and the Independent Slovak

\footnotetext{
${ }^{1}$ Ivan Franko National University of Lviv, Ukraine
} 
State (1939-1944) however, did not satisfy the Transcarpathians themselves, who in 1939 made a choice on the benefit of the Carpathian Ukraine" [1].

The ideas that threatened the integrity of the Ukrainian ethno-speaking space,were stimulus to the writing of a considerable number of scientific works, which discrowned all sorts of myths about the separate Transcarpathians. Famous linguists, in particular: V. Nimchuk, M. Mishanych, P. Chuchka, J. Dzendzelovsky scientifically justifed and proved that the autochthonous population of historical Transcarpathia is part of the Ukrainian ethno-speaking environment. It should be noted that after such scientifically substantiated publications, which denied all autonomy of the "Rusyn" ethnic group, Ukrainian scientists have suffered much criticism. At their address, were made criticism of the communist or totalitarian concept, which violated the rights of the ethnic "Rusyn" people.

Despite the extremely difficult situation that prevailed in the modern Transcarpathian region of those days, autochthonous people have always associated themselves as part of all-ukrainian ethnos. According to the famous historian, linguist and church figure, Michaila Luchkaya, dialect of Carpathian Rusy belong to the Ukrainian language foundation.

At this time, continue the development such pseudo-scientific theories of ethnocultural autonomy of individual regions. As a result, has became the situation in the Crimea and the Donbass region.

On the territory of modern Transcarpathia, the ideology of the region autonomy is carried out by the so-called neo-rusins. Their propaganda is based on groundless inventions about the specificity of the Transcarpathian language, which in fact is a variant of the Ukrainian literary language. Linguist L. Beley well-known in Ukraine and abroad considered that the neo-Rusyn movement "was, is and will continue to be a geopolitical doctrine whose significant destructive potential is an important component of the modern hybrid war conducted by imperial and revanchist forces against Ukraine" [1, p. 16].

It should be noted that the inhabitants of historical Transcarpathia from time immemorial attributed themselves to the Ukrainian people and the only linguistichistorical heritage. According to P. Chuchki, Transcarpathians "felt their ethnic belonging to Russian, the Eastern Slavic, did not identify themselves with either the Slovaks, nor the Poles, nor with the Serbs or Croats. But this feeling was on lower, tribal, and not national level. Even the intellectuals, searching for their national foundations and landmarks, did not always have the quality in question, to which Russians genetically or typologically it belongs - to Russians, to Ukrainians or simply to Ruski ..." [3, p. 18].

The well-known scientist V. Birchak emphasizes that writing used by inhabitants of Transcarpathia belongs to all-Ukrainian language fund. According to V. Birchak, in the language of Transcarpathians perform "the same directions, motives, ideas, the same competitions. But because Subcarpathian Rus' always lived in another political life, was dependent on other political and cultural centers, we see some differences in its culture and its writing" $[2$, p. 5]. 
During the interwar times, on the formation of linguistic belongings of Transcarpathians, a significant influence made national school and cultural organizations, which had pro-Ukrainian direction. Also significant influence was on the side of the Galician intellectuals (linguists, ethnographers), who scientifically proved the fact that Transcarpathians, their language and culture are the property of all-Ukrainian history.

At the present time, it is necessary to pay attention to formation and development of the state, to any manifestations of language imbalance that may lead to geopolitical threat of the country. In order to prevent such manifestations, it is necessary to introduce a language policy, which should regulate at the legislative level such manifestations that threatening the integrity of the state.

\section{References:}

1. Beley L. (2017). "Rusynskyi" separatyzm: natsiyetvorennya in vitro ["Rusynsky" separatism: nationbuilding in vitro]. Kyiv: Tempora. (in Ukraine).

2. Birchak V. (1993). Literaturni stremlinna Pidkarpatskoi Rusi [Literary aspirations of Pubcarpathian Rus]. Uzhgorod. (in Ukraine)

3. Chuchka P. P. (2005). Natsionalna svidomist zakarpatskykh ukraintsiv u XX stolitti: etnolinhvistychnyi ta kulturno-istorychnyi aspect [National consciousness of Transcarpathian Ukrainians in the twentieth century ethnolinguistic and cultural-historical aspect]. Uzhorod. (in Ukraine) 